\title{
Preschool Transition Skills Assessment Scale: Its Development, Validity and Reliability Studies
}

\author{
Hatice BAKKALOĞLU*
}

\begin{abstract}
The purpose of this study is to develop a valid and reliable scale that is considered necessary for assessment of transition skills acquired by preschool children with and without developmental delays. At development stage of the PTSAS, a scale has been prepared by reviewing the related literature, interviewing with administrators and teachers of preschool programs, analyzing studies of videotape recordings of preschool programs. Thirty-five teachers have assessed 21 and 277 children with and without development delays. For the validity of the PTSAS, construct validity, item analysis, and criterion validity have been performed. For the reliability of the PTSAS, internal consistency of scale, interobserver consistency, and test-retest reliability have been checked. The result showed that PTSAS is a valid and reliable instrument.
\end{abstract}

Key Words: Transition, transition skills, Preschool Transition Skills Assessment Scale (PTSAS)

\section{SUMMARY}

Background/Problem Statement: Transition skills are defined as behaviors/skills that facilitate the transition between programs by helping children to adapt to the new environment. The transitions are critically important for all children who are transiting inside and/or between programs. Although

\footnotetext{
* Instructor, Dr., Ankara University, Faculty of Educational Sciences, Department of Special Education, hbceber@yahoo.com
} 
many factors influencing the transition have been identified, the main ones have been recognized as the children themselves and their acquired skills. Any legal arrangements oriented to planning of preschool transition services and studies related the transition processes are not available in Turkey. The purpose of this study is to develop a valid and reliable scale that is considered necessary for assessment of transition skills acquired by children with and without developmental delays aged between 3 and 6 years.

Methods: At development stage of the PTSAS, a draft form has been prepared by reviewing the related literature, interviewing with administrators and teachers of preschool programs, analyzing studies of videotape recordings of preschool programs. After this process, a test form has been developed in accordance with suggestions of experts' opinions concerning the draft form. Thirty-five teachers working in 12 preschool have assessed 21 children with development delays and 277 children without development delays aged between 3 and 6 years by using the test form. For the validity of the PTSAS, construct validity by using factor analysis, item analysis, and criterion validity have been performed. For the reliability of the PTSAS, internal consistency of scale, interobserver consistency, and test-retest reliability have been checked.

Findings and Result: For the construct validity of the PTSAS, initially Principal-Components Analysis has been performed and then, Varimax Rotation Technique has been used for two factors. As a result of Varimax Rotation Technique it is observed that factor 1 was explaining $49.9 \%$ of total variance and factor 2 was explaining $7.8 \%$ of total variance. It is found that all items in the scale can differentiate the subgroup and upper group for the transition skills $(\mathrm{p}<.01)$ and item-total correlation coefficient is .43-.80 ( $<<.01)$. In connection with criterion validity, it is initially found that the correlation between scores obtained from Social Skill Scale and Social-Communicational Skills factor in PTSAS of 124 children is $.70(p<.001)$. Secondly, it is observed that there is a significant difference $(p<.01)$ between means of factor 1 , factor 2 and total scores that the children with and without development delays obtained from PTSAS. During the first reliability study it is observed that, Cronbach Alfa internal coefficients for factor 1 , factor 2 and total score are $.95, .85$ and .95 respectively; and also it is found that Sperman Brown internal coefficients are $.78, .93$ and .92 respectively. Additionally during test-retest reliability study, it is shown that correlation coefficients of factor 1 , factor 2 and total score are .70 , .58 and $.70(\mathrm{p}<.01)$ between two assessments conducted in 15 days intervals. During assessments performed by four observers on 9 children by using PTSAS, it is found that there is an interobserver consistency concerning factor 1 , factor 2 and total score. The result showed that PTSAS is a valid and reliable instrument for assessment of transition skills of preschool children with and without developmental delays.

Recommendations: In addition to PTSAS, other assessment procedures such as direct observation, interview etc., for assessment of preschool transition skills of children with and without development delays can be used. In the light of those assessments, conducting the studies about teaching transition skills will be facilitated the children's adaptation to new programs. 


\title{
Okulöncesi Geçiş Becerilerini Değerlendirme Ölçeği'nin Geliştirilmesi: Geçerlik ve Güvenirlik Çalıșmaları*
}

\author{
Hatice BAKKALOĞLU**
}

\begin{abstract}
ÖZ. Bu çalışmanın amacı, gelişimsel geriliği olan ve olmayan okulöncesi dönemdeki 3-6 yaş çocuklarının geçiş becerilerini değerlendirmek için gereksinim duyulan geçerli ve güvenilir bir ölçeğin geliştirilmesidir. Okulöncesi Geçiş Becerilerini Değerlendirme Ölçeği (OGBDÖ) geliştirilirken alan yazın incelemesi, okulöncesi programların yöneticileri ve öğretmenleriyle görüşmeler, okulöncesi programlarda yapılan video kayıtlarının analizi çalışmaları yapılmıştır. 12 okulöncesi kurumda çalışan 35 öğretmen, 21 gelişimsel geriliği olan ve 277 gelişimsel geriliği olmayan çocuğu OGBDÖ’ni kullanarak değerlendirmiştir. OGBDÖ'nin geçerliği incelenirken faktör analizi, madde analizi ve ölçüt geçerliği çalışmaları yapılmıştır. OGDBÖ’nin güvenirliği incelenirken ise, iç tutarlık katsayısı, test-tekrar test korelasyonu ve değerlendirmeciler arası tutarlık çalışmaları yapılmıştır. Sonuçlar OGBDÖ’nin geçerli ve güvenilir bir araç olduğunu göstermiştir.
\end{abstract}

Anahtar Sözcükler: Geçiş, geçiş becerileri, Okulöncesi Geçiş Becerilerini Değerlendirme Ölçeği (OGBDÖ)

\footnotetext{
* Bu çalışma Prof. Dr. Bülbin Sucuoğlu danışmanlığında yapılan "Etkinliğe Dayalı Müdahale Programının 3-6 Yaş Gelişimsel Geriliği Olan Çocukların Geçiş Becerilerine Etkisi" adlı doktora tez çalışmasının bir bölümünden özetlenerek hazırlanmış ve 17. Ulusal Özel Eğitim Kongresi'nde (15-17 Kasım 2007, Çeşme/İzmir) sözlü bildiri olarak sunulmuştur.

** Öğr. Gör. Dr. Ankara Üniversitesi Eğitim Bilimleri Fakültesiözel Eğitim Bölümü, hbceber@yahoo.com
} 


\section{GíRIȘ}

Geçiş değiş̧iklik, değişiklik ise herkes için güçlük demektir. Çocukların eğitiminde değişmeyen süreçlerden birisi, çocukların programların içinde/arasında geçiş yapmasıdır (Rous \& Hallam, 1998). Bütün çocuklar erken yaşlarında geçişlerle yüz yüze gelmektedir, ancak gelişimsel geriliği olan çocuklar, olmayan çocuklara göre daha sık ve yoğun geçiş deneyimi yaşayabilmektedir (Hanson, 1999). Chandler (1993) geçişi, "bir programdan diğerine ya da bir hizmet modelinden diğerine hareket etme süreci" olarak tanımlamıştır (Akt. Bruder \& Chandler, 1993). Geçişler, alan yazında iki şekilde sınıflandırılmaktadır. İlk sınıflamada geçiş (Kagan, 1992), "dikey" (zaman içinde sıralı olarak bir sistemden diğerine katılım) ve "yatay" (aynı zaman diliminde farklı yerlerde ve farklı kişilerce sunulan hizmetlere katılım) olarak (Akt. Rosenkoetter, Whaley, Hains, \& Pierce, 2001) sınıflandırılmaktadır. İkinci sınıflandırmada geçiş, "gelişimsel" (yaşa dayalı, ardışık programlara katılım), "gelişimsel olmayan" (gelişimsel geriliği olmayan akranlarla birlikte olma derecesi değişen programlara katılım) ve "sınıf-içi" (merkeze dayalı programlarda bir etkinlikten diğerine katılım) olarak (Wolery, 1989) sınıflandırılmaktadır. Ancak "geçiş" denildiğinde akla ilk gelen, çocukların bir programdan diğerine geçmesini içeren dikey/gelişimsel geçişlerdir (Wolery, 1999).

Geçiş çalışmaları, çocukların yeni ortamda karşılaşacağı farklılıklara çocukları ve aileleri hazırlayarak, okula giriş yapmayı kolaylaştırmaktadır (Lombardi, 1992). Geçiş süreci rahat/yumuşak olduğunda olumlu sonuçlar ortaya çıkmakta, güçlükle karşılaşıldığında ise bu süreç çocukların yaşamında bir sınav halini alabilmekte, özellikle gelişimsel sorunu olan çocuklar daha fazla problem yaşayabilmektedir (Pianta \& Kraft-Sayre, 1999). Küçük çocukların geçişleri konusundaki ilk tartışmalar, Amerika Birleşik Devletleri'nde yoksul ailelerin çocuklarına ve özel gereksinimli çocuklara hizmet veren Head Start okulöncesi programına katılan ailelerin geçiş konusundaki endişelerini dile getirmeleriyle başlamıştır. Günümüzde Amerika Birleşik Devletleri'nde gelişimsel geriliği olan çocuklar için, doğumdan 3 yaşına kadar Bireyselleştirilmiş Aile Hizmet Planı'nın bir parçası olarak geçiş planlaması yapılması zorunludur (Repetto \& Correa, 1996; Rosenkoetter ve ark., 2001). Geçiş planlaması hizmetlerin sürekliliğini sağlamak, değişime uyum sağlamaya yardım ederek ailelerin rahatsızlıklarını en aza indirmek, yasal gereklilikleri yerine getirmek ve geçiş yapılacak programda çocuğun işlevsel olmasını sağlamak amacıyla yapılmaktadır (Wolery, 1989). Bu amaçlara ulaşmada sistem, aile ve çocuk düzeyinde problemler yaşanmaktadır. Bu problemleri çözebilmek için geçişi etkileyen faktörler ele alınması gerekmektedir (Wolery, 1999). Yönetsel 
konuların, gönderen (çocuğun ayrıldı ̆ı) ve alan (çocuğun geçiş yaptığı) programda çalışan personelin, ailelerin ve çocukların geçişi etkilediği, ancak geçişi etkileyen temel faktörün çocuklar ve çocukların sahip olduğu beceriler olduğu bildirilmektedir (Bruder \& Chandler, 1993; Hanson, Beckman, Horn, Marquart, Sandall, Greig, \& Brennan, 2000; Maxwell \& Eller, 1994; Rous, Hemmeter, \& Schuster, 1994; Rule, Fiechtl, \& Innocenti, 1990; Wolery, 1999). Geçiş yapılan programlar arasındaki farklılıklar nedeniyle, gönderen programda sergilenen başarılı performansın alan programda da başarılı performans sergilenmesini garanti altına almayacağı belirtilmektedir (Carta, Atwater, Schwartz, \& Miller, 1990). Gelişimsel geriliği olan çocukların geçişlerini iyileştirmeye yönelik çalışmalarda gönderen ve alan programlar arasındaki farklılıkları en aza indirme ve/veya çocukları farklılıklarla baş etmek için hazırlamaya odaklanılmaktadır (Kemp \& Carter, 2000). Çocukların okula hazır bulunuşluğunu arttırmada hem çocukları programa hazırlamanın (çocukların becerilerini arttırmak gibi) hem de programı çocuklara hazırlamanın (personel sağlamak gibi) önemli ve gerekli olduğu vurgulanmaktadır (Katz, 1991; Rous \& Hallam, 1998).

Erken çocukluk dönemindeki çocuklarla çalışan pek çok eğitimci, okulöncesi dönemdeki çocukların yeni programlarda bağımsız olarak işlevlerini yürütebilmesi için gerekli olan becerileri belirlemeye çalışmaktadır (Westling \& Fox, 2000). Bu beceriler geçiş becerileri (transition skills) olarak adlandırılmaktadır. Sosyal, iletişim, özbakım, motivasyon, problem çözme, akademik hazırlık, çalışma ve kendini yönetme becerilerini kapsayan geçiş becerileri (Wolery, 1999), bazı çalışmalarda yaşam becerileri (survival skills) olarak da adlandırılmaktadır (Rule ve ark., 1990; Kemp \& Carter, 2000). Çocukların geçiş yaptığı programların birbirinden farklılaşması nedeniyle, çocukları yeni programda işlevsel olmaya hazırlamak için yeni ortamlarda kullanılan özel becerilerin değerlendirilmesi gerekmektedir. Bu değerlendirmenin mantığı; çocuğun geçiş yapacağı çevreyi saptamak, bu çevrede gereksinim duyulan becerileri/davranışları belirlemek ve hâlihazırdaki programda amaçları/hedefleri oluştururken bu becerileri/davranışları çocuğun öğretim programına yerleştirmektir (Fowler, Schwartz, \& Atwater, 1991; Katims \& Pierce, 1995).

Okulöncesinde geçiş yapan 3-6 yaş çocukların sahip olması gereken geçiş becerilerini değerlendirmek amacıyla, farklı becerilerin yer aldığ değerlendirme araçlarının geliştirildiği ve bu araçlardaki becerilerin farklı şekillerde sinıflandırıldığ 1 görülmektedir. Byrd ve Rous tarafindan geliştirilen Yardımcı Giriş Düzeyi Becerileri Kontrol Listesi (Helpful Entry Level Skills Checklist) okulöncesi geçişte 3-6 yaş çocuklarının sosyal, 
davranışsal ve işlevsel becerilerini değerlendirmek için kullanılmaktadır (Akt. Rous \& Hallam, 1998). Rosenkoetter, Hains ve Fowler (1994) tarafindan geliştirilen Anasınıfina Girişte Kullanılan Akademik Olmayan Beceriler Kontrol Listesi (Nonacademic Skills Useful For Transition Into Kindergartens Checklist) ile de anasınıfına geçişte önemli beceriler değerlendirilmektedir. $\mathrm{Bu}$ değerlendirme araçlarında genellikle bağımsız/işbirliğiyle oyun oynama/çalışma ve sınıf kurallarına uyma gibi sosyal ve akranlarla/yetişkinlerle etkileşim kurma gibi iletişim becerilerine ağırlık verildiği görülmektedir. Ancak bu değerlendirme araçlarının psikometrik özelliklerine ilişkin verilere ulaşılamamıştır. Bu değerlendirme araçlarından Yardımcı Giriş Düzeyi Becerileri Kontrol Listesi, özellikle Amerika Birleşik Devletleri'nde 26 eyalette ve İsrail'de başarıyla uygulanana Okul Eğitimine Ardışık Geçiş Projesi'nde (Sequenced Transition to Education in the Public Schools Project) okulöncesinde geçiş yapan çocukların geçiş becerilerini değerlendirmek amacıyla yoğun şekilde kullanılmaktadır (Rous, Hemmeter, \& Schuster, 1994; Rous, 1999).

Günümüzde gelişimsel geriliği olan ve olmayan çocukların ve ailelerinin gereksinimlerini karşılamak için farklı felsefeleri, hizmet sağlama modellerini, değerlendirme ve eğitsel yaklaşımları temel alan çeşitli erken çocukluk eğitimi ve erken çocukluk özel eğitimi programları yürütülmektedir. Bu programlarda üzerinde önemle durulan konulardan biri olan geçiş, gelişimsel geriliği olan ve olmayan çocuklara ve ailelerine götürülen hizmetlerin yararllğını etkileyen faktörlerden birisidir. Türkiye'de okulöncesi dönemdeki geçiş hizmetlerine/planlamalarına yönelik yasal düzenlemeler bulunmamasına karşın, konuyla ilgili sadece bir çalışma bulunmaktadır. Kargın, Akçamete ve Baydık (2001) tarafından okulöncesi dönemde çocuğu bulunan ailelerin geçiş sürecindeki gereksinimlerini belirlemek amacıyla yürütülen çalışmada 24 maddeden oluşan Anasınıfına Geçişte Aile Gereksinimleri Belirleme Ölçeği geliştirilmiş, ölçek 3-5 yaşındaki 94 işitme engelli çocuğun anne-babasına uygulanarak geçerlik ve güvenirlik çalışmaları yapılmıştır. Çalışmanın sonucunda anne-babaların anasınıfına geçişle ilgili olarak ölçekte yer alan tüm maddelere gereksinim duydukları ve anne-baba gereksinimlerinin çocuğun cinsiyetine, yaşına, eğitime başlama yaşına, anne-babanın eğitim durumuna ve yaşına göre farklılaşmadığı bulunmuştur.

Ülkemizde de erken çocukluk eğitimi ve erken çocukluk özel eğitimi programlarıyla gelişimsel geriliği olan ve olmayan çocuklara değişik bağlamlarda hizmetler verilmektedir. Bu programlarda çocukların sonraki programlara (anaokulu ya da anasınıfi) daha iyi hazırlanabilmesi için, geçiş becerilerinin değerlendirilmesi ve değerlendirme sonuçlarına göre hazırlanan 
programlarla geçiş becerilerin öğretilmesi yoluyla, çocukların geçiş yapacakları programa daha kolay kabul edilmelerini sağlanacak, işlevsellikleri arttırılacak ve sınıfa uyumlarını kolaylaştıracaktır. Bu nedenle ülkemizde 3-6 yaş gelişimsel geriliği olan ve olmayan çocukların geçiş becerilerini değerlendirmek için bir ölçme aracına gereksinim olduğu düşünülmektedir. $\mathrm{Bu}$ düşünceden hareketle çalışmada, 3-6 yaş okulöncesi çocukların geçiş becerilerini değerlendirmek için bir ölçme aracının geliştirilmesi ve geçerlik ile güvenirlik çalışmalarının yapılması amaçlanmıştır.

\section{YÖNTEM}

\section{Araștırma Grubu}

Araştırma grubunu Ankara ilinde farklı sosyoekonomik düzeyleri temsil ettiği düşünülen okullar listesinden, kolayca elde edilen gruplara uygulanan tesadüfî örnekleme yoluyla seçilmiş 12 okulda eğitim gören 3-6 yaşındaki (36-72 ay) 298 çocuk oluşturmaktadır. Bu okullardan 2'si özel eğitim okuludur ve sadece gelişimsel geriliği olan çocuklara hizmet vermektedir. 4 okulda ise kaynaştırma uygulamaları yürütülmekte ve bu okullara hem gelişimsel geriliği olan hem de olmayan çocuklar devam etmektedir. Genel eğitim veren 6 okulda ise sadece gelişimsel geriliği olmayan çocuklara hizmet verilmektedir. 298 çocuktan $21^{\prime}$ i gelişimsel geriliği olan, 27'i ise gelişimsel geriliği olmayan çocuktur. Gelişimsel gerilik tanısı, üniversite hastanelerinin ilgili bölümlerince konulmuştur. Toplam 12 okulda çalışan 35 öğretmen, çocukları Okulöncesi Geçiş Becerilerini Değerlendirme Ölçeği (OGBDÖ) Deneme Formu ile değerlendirmişlerdir. Araştırma grubunda yer alan çocuklar ve bu çocuklar için deneme formunu dolduran öğretmenler ve öğretmenlerin çalıştıkları sınıflar ve okullara ilişkin bilgiler Tablo 1'de verilmiştir.

Tablo 1. Araştırma Grubunda Yer alan Çocuklar, Öğretmenler ve Okullara İlişkin Bilgiler

\begin{tabular}{lcccccccccc}
\hline & \multirow{2}{*}{ Okul } & \multirow{2}{*}{ Sinıf } & \multirow{2}{*}{ Öğretmen } & \multicolumn{2}{c}{$\begin{array}{c}\text { Çocuk } \\
\text { Yaş }\end{array}$} & \multicolumn{2}{c}{$\begin{array}{c}\text { Cocuk } \\
\text { Cinsiyet }\end{array}$} & \multicolumn{2}{c}{$\begin{array}{c}\text { Cocuk } \\
\text { GG* }\end{array}$} \\
\cline { 5 - 10 } & & & & $3-4$ & $5-6$ & $\mathrm{~K}$ & $\mathrm{E}$ & $\begin{array}{c}\text { GG } \\
\text { Olan }\end{array}$ & $\begin{array}{c}\text { GG } \\
\text { Olmayan }\end{array}$ \\
\hline Özel eğitim & 2 & 4 & 4 & 4 & 12 & 1 & 15 & 16 & - \\
Kaynaştırma & 4 & 9 & 9 & 19 & 28 & 25 & 22 & 5 & 42 \\
Genel & 6 & 22 & 22 & 64 & 171 & 104 & 131 & - & 235 \\
Toplam & 12 & 35 & 35 & 87 & 211 & 130 & 168 & 21 & 277
\end{tabular}

*GG: gelişimsel gerilik 


\section{OGBDÖ’nin Geliștirilmesi}

\section{Alan yazın taraması}

Ölçeğin geliştirilmesi sürecinde öncelikle alan yazın taraması yapılmış, okulöncesi çocukların geçiş becerilerini değerlendirmede kullanılan araçlar (Anasınıfına Girişte Kullanılan Akademik Olmayan Beceriler Kontrol Listesi, Rosenkoetter ve ark., 1994; Yardımc1 Giriş Düzeyi Becerileri Kontrol Listesi, Akt. Rous \& Hallam, 1998) incelenmiş ve bu araçlarda yer alan geçiş becerileri belirlenmiştir. İncelenen değerlendirme araçlarının genellikle "sınıf kuralları ve rutinleri izleme, isteklerini/gereksinimlerini ifade etme, diğerleriyle işbirliği yapma, yönergelere uyma, sıra olma, yetişkinlerle/akranlarla etkileşim kurma, karar verme" gibi ağırlıklı olarak sosyal/iletişimsel becerileri kapsadığı görülmüştür.

\section{Okulöncesi programların yöneticileri ve öğretmenleriyle yapılan görüşmeler}

Okulöncesi programlara başlamak için önemli olan geçiş becerilerini belirleyebilmek amaciyla, 3-6 yaş çocuklara eğitim veren 8 anaokulundan (2 özel eğitim, 3 genel, 3 kaynaştırma) 8 yönetici ve 20 öğretmenle araştırmacı tarafından görüşmeler yapılmıştır. Yarı yapılandırılmış görüşmelerde yöneticilere "Okulunuza öğrenci kabul ederken, çocukların hangi becerilere sahip olmasını bekliyorsunuz?" sorusu sorulmuştur. Öğretmenlere ise "Sınıfınızda yeterli olduğunu düşündüğünüz çocuklar hangi becerilere sahip? Sınıfa uyum sağlamak için çocuklar hangi becerilere sahip olmalı? Bir çocuğun sınıfınıza kabul edilebilmesi için en önemli beceriler nelerdir?" soruları sorulmuştur. Yanıtlar ses kayıt cihazı kullanılarak kaydedilmiş, kayıtlar araştırmacı tarafından çözümlenmiş ve okulöncesi programlarda önemli olduğu sıklikla ifade edilen beceriler listelenmiştir. Görüşmeler sonucunda okul yöneticilerinin ve öğretmenlerin "tuvalet eğitimi, giyinme/soyunma, yemek yeme ve temizlik" gibi özbakım becerilerine öncelik verdikleri ve bu becerileri "olmazsa olmaz" diye nitelendirdikleri; alınyazında sıklıkla yer almasına karşın, "yönergelere uyma, grup etkinliklerine katılma, sira olma, verilen görevi tamamlama" gibi sosyal/iletişimsel becerilere daha az öncelik verdikleri görülmüştür.

\section{Okulöncesi programlarda çekilen video kayıtların analizi}

Alan yazında geçiş becerileri belirlenirken, geçiş yapılacak çevrenin incelenmesi ve bu çevrede kullanılan becerilerin gözlenerek belirlenmesinin gerekliliği sıklıkla vurgulanmaktadır (Carta ve ark., 1990; Fowler ve ark., 1991; Rule ve ark., 1990). Bu nedenle okulöncesi programlardaki çocukların sıklıkla kullandıkları becerileri belirlemek amacıyla, toplam 7 sınıfta (2 özel 
eğitim, 3 genel, 2 kaynaştırma), 09.30-12.30 saatleri arasındaki etkinliklerde 1,5 saatlik video kayıtları yapılmıştır. $\mathrm{Bu}$ sınıflarda serbest zaman etkinlikleri, masa etkinlikleri, hikâye saati, yemek saati gibi etkinliklerin her birinin ilk 10-15 dakikalık bölümü kaydedilmiş, kayıtlar daha sonra araştırmacı tarafından çözümlenerek okulöncesi programda öğretmenlerin çocuklardan kullanmalarını istedikleri beceriler listelenmiştir. Öğretmenlerin çocuklardan "yönergelere uyma, grup etkinliklerine katılma, yerinde oturma, sıra olma, soru sorulduğunda yanıtlama, dinleme, kurallara uyma, bağımsız çalışma ve materyalleri toplama" gibi sosyal-iletişimsel becerileri kullanmalarını istedikleri gözlenmiştir.

Alan yazın taraması, okulöncesi yöneticileri ve öğretmenleriyle görüşmeler ile video kayıtların analizi sonucunda belirlenen becerilerin incelenmesi sonucunda, 25 beceriden oluşan bir OGBDÖ Taslak Formu oluşturulmuştur. Oluşturulan taslak form konusunda, alanda çalışan uzmanların görüşleri alınmıştır. Uzmanların önerileri doğrultusunda OGBDÖ Deneme Formu oluşturulmuştur.

\section{Verilerin Toplanması ve Analizi}

Veriler, öğretmenlerin OGBDÖ Deneme Formu'nu sınıflarındaki her çocuk için doldurmaları yoluyla toplanmıştır. Farklı 12 okulöncesi kurumda çalışan 35 öğretmen, sınıflarında en az 6 aydır tanıdıkları çocukları deneme formunu kullanarak değerlendirmişlerdir. Değerlendirmede öğretmenlerden, ölçekteki maddeleri dikkatle okuduktan sonra çocuğun becerisini beşli derecelendirmeyle (1: Tamamen yardımla yapar, 5: Tamamen yardımsız yapar) değerlendirmeleri istenmiştir. Toplanan veriler üzerinde OGBDÖ’nin geçerlik ve güvenirlik çalışmaları yapılmıştır.

\section{BULGULAR}

\section{OGBDÖ'nin Geçerlik Çalışmaları}

\section{Faktör analizi}

OGBDÖ’nin yapı geçerliğini belirlemek amaciyla ilk olarak Temel Bileşenler Analizi yapılmış, daha sonra ölçekte yer alan maddelerin kuramsal yapıları dikkate alınarak iki faktöre göre Varimax Dik Döndürme Tekniği kullanılmıştır. Maddelerin sadece bir faktörde yüksek yük değerine (.45 ve üstü) diğer faktörde ise düşük yük değerine sahip olması ölçüt alındığından (Büyüköztürk, 2002), bir madde (21.) iki faktörde de göreli olarak yüksek yük değerine (.40 ve .41) sahip olması nedeniyle ölçekten çıkarılmıştır. Varimax Dik Döndürme Tekniği sonucunda faktör 1'in toplam varyansın \%49,9'unu, faktör 2'nin ise \%7,8'ini açıkladığı görülmüştür. Bu iki faktörde yer alan maddelerin kuramsal içerikleri göz önüne alınarak faktör 1'deki 19 beceriye "Sosyal-İletişimsel Beceriler Alt Ölçeği" (SİB); faktör 2'de yer alan 5 beceriye ise "Özbakım Becerileri Alt Ölçeğil” (ÖBB) 
adı verilmiştir. Faktörlerin birbirleriyle ve toplam puanla korelasyonlarına (Pearson Correlation) bakılmış ve iki faktör arasındaki korelasyonun .60 $(\mathrm{p}<.01)$, faktör 1 ile toplam puan arasındaki korelasyonun $.98(\mathrm{p}<.01)$ ve faktör 2 ile toplam puan arasındaki korelasyonun ise $.73(\mathrm{p}<.01)$ olduğu bulunmuştur. Ölçekteki maddelerin faktör analizi sonuçları Tablo 2'de verilmiştir.

Tablo 2. OGBDÖ'nde Yer Alan Maddelerin Faktör Analizi Sonuçları

\begin{tabular}{|c|c|c|c|c|}
\hline \multirow[t]{2}{*}{ Maddeler* } & \multirow{2}{*}{$\begin{array}{c}\text { Döndürme } \\
\text { Öncesi Faktör } \\
\text { Yük Değerleri }\end{array}$} & \multicolumn{2}{|c|}{$\begin{array}{l}\text { Varimax Dik } \\
\text { Döndürme }\end{array}$} & \multirow{2}{*}{$\begin{array}{c}\text { Ortak } \\
\text { Faktör } \\
\text { Varyansı }\end{array}$} \\
\hline & & Faktör 1 & Faktör 2 & \\
\hline 1. Tuvaletini yapar.(1) & .55 & .13 & .83 & .71 \\
\hline 3. Giyinir ve soyunur.(2) & .58 & .20 & .76 & .63 \\
\hline 4. Ellerini yıkar ve kurular.(3) & .71 & .36 & .76 & .72 \\
\hline 2. Yemek yer.(4) & .45 & .07 & .73 & .55 \\
\hline 5. Dişlerini firçalar.(5) & .59 & .31 & .63 & .50 \\
\hline $\begin{array}{l}\text { 17. Yetişkinler ya da arkadaşları konuşurken onları } \\
\text { dinler.(6) }\end{array}$ & .77 & .77 & .22 & .64 \\
\hline 12. İstenildiğinde yerinde oturur ve bekler.(7) & .69 & .75 & .10 & .57 \\
\hline 8. Yönergelere uyar.(8) & .70 & .74 & .12 & .57 \\
\hline 9. Sorulara yanit verir.(9) & .82 & .74 & .36 & .68 \\
\hline 18. Teşekkür eder.(10) & .74 & .73 & .22 & .59 \\
\hline 13. Sira olur ve sirada bekler.(11) & .70 & .71 & .18 & .54 \\
\hline $\begin{array}{l}\text { 16. Verilen görevi istenilen zamanda ve uygun } \\
\text { şekilde tamamlar.(12) }\end{array}$ & .80 & .71 & .37 & .64 \\
\hline $\begin{array}{l}\text { 19. Oyuncakları ya da materyalleri yerinden alır, işi } \\
\text { bitince toplar ve yerine kaldırır.(13) }\end{array}$ & .70 & .71 & .16 & .54 \\
\hline $\begin{array}{l}\text { 23. Arkadaşlarının etkinliklerini bozmaktan } \\
\text { kaçınır.(14) }\end{array}$ & .66 & .71 & .10 & .52 \\
\hline $\begin{array}{l}\text { 7. Okula ya da kendisine ait materyalleri ya da } \\
\text { yiyecekleri diğerleriyle paylaşır.(15) }\end{array}$ & .70 & .69 & .22 & .53 \\
\hline $\begin{array}{l}\text { 24. Yeni şeyler öğrenirken yetişkinleri ya da } \\
\text { arkadaşlarını taklit eder.(16) }\end{array}$ & .74 & .68 & .32 & .56 \\
\hline $\begin{array}{l}\text { 14. Başa çıkamadığ durumlarda yetişkinden ya da } \\
\text { arkadaşından yardım ister.(17) }\end{array}$ & .78 & .67 & .39 & .61 \\
\hline $\begin{array}{l}\text { 20. Günaydın ya da merhaba gibi sözcükleri ya da } \\
\text { jestleri kullanarak diğerleriyle selamlaşır.(18) }\end{array}$ & .71 & .66 & .27 & .52 \\
\hline $\begin{array}{l}\text { 15. Bir etkinlik üzerinde } 3-5 \text { dakika süreyle } \\
\text { çalışır.(19) }\end{array}$ & .77 & .65 & .41 & .60 \\
\hline $\begin{array}{l}\text { 22. İstendiğinde bir etkinlikten diğerine kolayca } \\
\text { geçiş yapar.(20) }\end{array}$ & .78 & .65 & .42 & .61 \\
\hline $\begin{array}{l}\text { 10. Serbest zaman ya da yapılandırılmış grup } \\
\text { etkinliklerine katılır.(21) }\end{array}$ & .81 & .64 & .50 & .66 \\
\hline 11. İsteklerini ya da ihtiyaçlarını belirtir.(22) & .77 & .64 & .42 & .59 \\
\hline $\begin{array}{l}\text { 25. Yetişkinlerin ya da arkadaşlarının dikkatini } \\
\text { uygun şekilde (el kaldırarak, seslenerek ya da } \\
\text { dokunarak) çeker.(23) }\end{array}$ & .64 & .62 & .20 & .43 \\
\hline $\begin{array}{l}\text { 6. Jestlerle, mimiklerle, seslerle, sözcüklerle } \\
\text { yetişkinlerle ya da arkadaşlarıyla iletişim kurar.(24) }\end{array}$ & .70 & .59 & .37 & .49 \\
\hline $\begin{array}{l}\text { 21. Anne-babasından ayrılır, yetişkinler ya da } \\
\text { arkadaşlarıyla kalmayı kabul eder.** }\end{array}$ & .56 & .40 & .41 & .33 \\
\hline
\end{tabular}


Tablo 2'de görüldüğü gibi, dik döndürme öncesi maddelerin faktör yük değerleri .45-.82 arasında değişmektedir. İki faktöre göre yapılan Varimax Dik Döndürme Tekniği sonrasında faktör 1'de yer alan maddelerin faktör yük değerlerinin .59-.77 arasında; faktör 2'de yer alan maddelerin faktör yük değerlerinin ise .63-.83 arasında değiştiği görülmektedir. $\mathrm{Bu}$ sonuçlar, ölçeğin hem tek faktörlü/tek ölçek hem de iki faktörlü/iki alt ölçekli olarak kullanılabileceğini göstermektedir (Büyüköztürk, 2002)

Tablo 3. OGBDÖ'nde Yer Alan Maddelerin Madde Analizi ve Madde-Toplam Puan Korelasyon Katsayıları Sonuçları

\begin{tabular}{|c|c|c|c|c|c|c|}
\hline \multirow[t]{2}{*}{ Maddeler } & \multicolumn{2}{|c|}{$\begin{array}{l}\text { Alt \%27 Grup } \\
\quad(\mathrm{n}=80)\end{array}$} & \multicolumn{2}{|c|}{$\begin{array}{l}\text { Üst \%27 Grup } \\
\quad(n=80)\end{array}$} & \multirow[t]{2}{*}{$\mathrm{t}^{*}$} & \multirow[t]{2}{*}{$\mathrm{r}^{*}$} \\
\hline & $\mathrm{x}$ & ss & $\mathrm{x}$ & ss & & \\
\hline 1 & 3.83 & 1.25 & 4.93 & .29 & -7.62 & .53 \\
\hline 2 & 3.77 & 1.34 & 4.75 & .62 & -5.89 & .43 \\
\hline 3 & 3.31 & 1.21 & 4.85 & .48 & -0.50 & .56 \\
\hline 4 & 3.90 & 1.29 & 5.00 & .00 & -7.57 & .70 \\
\hline 5 & 3.42 & 1.30 & 4.75 & .66 & -8.06 & .58 \\
\hline 6 & 3.28 & 1.24 & 4.91 & .32 & -11.29 & .68 \\
\hline 7 & 3.03 & 1.34 & 4.82 & .44 & -11.29 & .69 \\
\hline 8 & 3.15 & 1.14 & 4.92 & .30 & -13.34 & .69 \\
\hline 9 & 3.01 & 1.18 & 4.97 & .15 & -14.68 & .80 \\
\hline 10 & 3.23 & 1.07 & 4.96 & .24 & -14.04 & .79 \\
\hline 11 & 3.28 & 1.17 & 5.00 & .00 & -13.07 & .75 \\
\hline 12 & 3.18 & 1.17 & 4.90 & .34 & -12.56 & .68 \\
\hline 13 & 3.13 & 1.14 & 4.93 & .29 & -13.63 & .69 \\
\hline 14 & 3.13 & 1.02 & 4.96 & .19 & -15.61 & .76 \\
\hline 15 & 3.16 & 1.29 & 4.96 & .19 & -12.28 & .76 \\
\hline 16 & 2.70 & 1.17 & 4.85 & .42 & -15.41 & .79 \\
\hline 17 & 2.97 & 1.09 & 4.88 & .35 & -14.91 & .76 \\
\hline 18 & 2.83 & 1.34 & 4.85 & .42 & -12.76 & .72 \\
\hline 19 & 2.82 & 1.06 & 4.87 & .40 & -16.11 & .68 \\
\hline 20 & 2.88 & 1.35 & 4.91 & .32 & -13.04 & .69 \\
\hline 21 & 3.32 & 1.08 & 4.97 & .22 & -13.28 & .75 \\
\hline 22 & 3.01 & 1.24 & 4.86 & .38 & -12.68 & .65 \\
\hline 23 & 3.08 & 1.03 & 4.80 & .46 & -13.53 & .73 \\
\hline 24 & 3.35 & 1.35 & 4.88 & .38 & -9.78 & .61 \\
\hline
\end{tabular}

\section{Madde analizi}

OGBDÖ'nden elde edilen veriler üzerinde a) alt-üst grup ortalamaları farkına ve b) madde puanları ile toplam puanlar arasındaki korelasyona bakılmıştır (Tezbaşaran, 1997). Alt-üst grup ortalamaları farkına bakmak amacıyla ölçekten alınan toplam puanlar en düşükten en yükseğe doğru sıralanmış, her madde için alt ve üst \%27'lik grupların puan ortalamaları 
arasında fark olup olmadığına ilişkisiz örneklemler için t-testi ile bakılmıştır. Madde puanları ile toplam puanlar arasındaki ilişkiye bakmak amacıyla ölçekte yer alan her maddenin toplam puanı yordama gücünü belirleyebilmek için, her maddenin toplam puanla korelasyonu (Pearson Correlation) hesaplanmıştır. OGBDÖ'ndeki maddelerin madde analizi ve madde-toplam puan korelasyon katsayıları Tablo 3'de verilmiştir.

Tablo 3'de görüldüğü gibi, ilişkisiz örneklemler için t-testi sonucunda, ölçekteki tüm maddelerin alt ve üst grupları sahip oldukları geçiş becerileri açısından ayırt ettiği ve tüm maddelerin, madde-toplam puan korelasyon katsayılarının .43-.80 $(\mathrm{p}<.01)$ arasında olduğu bulunmuştur.

\section{Ölçüt geçerliği}

OGBDÖ'nin ölçüt geçerliğini test etmek amaciyla a) ölçeğin benzer yapıları ölçen bir ölçüm aracından alınan puanlarla ilişkisi incelenmiş, b) ölçeğin gelişimsel geriliği olan ve olmayan çocukları geçiş becerileri açısından ayırt edip etmediği araştırılmıştır. İlk çalışmada kullanılan Okulöncesi ve Anasınıfı Davranış Ölçekleri Merrell (Preschool and Kindergarten Behavior Scales; K.W. Merrell, 1994) tarafindan geliştirilmiş̧ ve Poyraz-Tüy (1999) tarafından Türkçe Formu'nun geçerlik ve güvenirlik çalışmaları yapılmıştır. Bu ölçeklerden Sosyal Beceri Ölçeği (SBÖ), OGBDÖ'nin Sosyal/İletişimsel Beceriler alt ölçeğinin ölçüt geçerliğini test etmek için kullanılmış, daha önce OGBDÖ ile değerlendirilen 124 çocuğun sosyal becerileri, SBÖ kullanılarak bir kez daha öğretmenleri tarafından değerlendirilmiştir. OGBDÖ'nin SIBB alt ölçeği ile SBÖ'nden elde edilen ortalama puanlar arasındaki korelasyona (Pearson Correlation) bakılmış ve iki ölçekten elde edilen puanlar arasındaki korelasyonun .70 ( $p<.001)$ olduğu bulunmuştur.

İkinci olarak, OGBDÖ kullanılarak değerlendirilen 21 gelişimsel geriliği olan çocuğun ölçekten aldıkları iki faktör ve toplam puanları, akranlarının puanları ile karşılaştıılmıştır. Bu amaçla öncelikli olarak gelişim geriliği olmayan 277 çocuk arasından yaş ve cinsiyetleri temel alınarak tesadüfî olarak 21 çocuk seçilmiş ve yeni bir örneklem oluşturulmuştur. İki grubun puan ortalamaları arasında fark olup olmadığına ilişkisiz örneklemler için t-testi ile bakılmış, analiz sonuçları Tablo 4'te verilmiştir. 
Okulöncesi Geçiş Becerilerini Değerlendirme Ölçeği nin Geliştirilmesi...285

Tablo 4. Gelişimsel geriliği Olan ve Olmayan Çocukların OGBDÖ Ortalama Puanları Arasındaki Farkın Anlamlılığı İçin t-Testi Sonuçları

\begin{tabular}{lccccc}
\hline \multicolumn{1}{c}{ Faktörler } & \multicolumn{2}{c}{ Gelişimsel Geriliği Olmayan } & \multicolumn{2}{c}{ Gelişimsel Geriliği Olan } & \multirow{2}{c}{ Grup $(\mathrm{n}=21)$} \\
& $\mathrm{x}$ & $\mathrm{ss}$ & $\mathrm{x}$ & $\mathrm{ss}$ & \\
\hline Faktör 1 (SİB) & 88.09 & 6.07 & 48.76 & 18.50 & 9.25 \\
Faktör 2 (ÖBB) & 22.95 & 3.59 & 17.09 & 6.53 & 3.59 \\
Toplam Puan & 114.04 & 7.15 & 65.85 & 21.93 & 8.97 \\
\hline
\end{tabular}

${ }^{*} \mathrm{p}<.01$

Tablo 4'te görüldüğü gibi, gelişimsel geriliği olan ve olmayan çocukların OGBDÖ'nden elde ettikleri faktör 1, faktör 2 ve toplam puan ortalamaları arasında anlamlı derecede fark olduğu, gelişimsel geriliği olan çocukların puanlarının akranlarından anlamlı derecede az olduğu ve aracın iki grubu ayırt ettiği bulunmuştur.

\section{OGBDÖ’nin Güvenirlik Çalıșmaları}

\section{İç tutarlılık}

İlk güvenirlik çalışması olarak OGBDÖ'nin iç tutarlılık katsayıları incelenmiştir. $\mathrm{Bu}$ amaçla Cronbach Alfa ve Sperman-Brown katsayıları incelenmiştir. Alan yazında .70-.80 güvenirlik değerlerinin, ölçme aracının araştırmalarda kullanılabilmesi için yeterli olduğu kabul edilmektedir (Özgüven, 1994). OGBDÖ’nin faktörler ve toplam puan için iç tutarlılık katsayıları sonuçları Tablo 5'de verilmiştir. Tabloda görüldüğü gibi faktör 1, faktör 2 ve toplam puan için Cronbach Alfa iç tutarlık katsayılarının sırasıyla $.95, .85$ ve .95 olduğu; Sperman Brown iç tutarlık katsayılarının ise sırasıyla $.78, .93$ ve .92 olduğu bulunmuştur.

Tablo 5. OGBDÖ'nin İ̧̧ Tutarlılık Katsayıları Sonuçları

\begin{tabular}{lcc}
\hline \multicolumn{1}{c}{ OGBDÖ } & Cronbach Alfa & Sperman-Brown \\
\hline Faktör 1 (SİB) & .95 & .78 \\
Faktör 2 (ÖBB) & .85 & .93 \\
Toplam Puan & .95 & .92 \\
\hline
\end{tabular}

\section{Test-tekrar test güvenirliği}

İkinci güvenirlik çalışması olarak OGBDÖ'nin test-tekrar test güvenirliğine bakılmıştır. Bu amaçla 13 öğretmen, 15 gün arayla 124 çocuğu OGBDÖ ile ikinci kez değerlendirmişlerdir. İki değerlendirme sonucunda elde edilen faktör 1 , faktör 2 ve toplam puanlar arasındaki korelasyon katsayıları (Pearson Correlation) hesaplanmış ve bu değerlerin sırasıyla .70, .58 ve $.70(\mathrm{p}<.01)$ olduğu bulunmuştur. 


\section{Değerlendirmeciler arası tutarlılık}

OGBDÖ'nin üçüncü güvenirlik çalışması olarak değerlendirmeciler arası tutarlılığa bakılmıştır. Bu amaçla 9 çocuk, çocukları iyi tanıyan 4 değerlendirmeci tarafından bağımsız olarak OGBDÖ kullanılarak değerlendirilmiştir. $\mathrm{Bu}$ değerlendirmeler arasında fark olup olmadığını incelemek amacıyla parametrik olmayan bir test olan ilişkili ölçümler için Friedman'ın iki yönlü varyans analizi kullanılmıştır. Analiz sonuçları Tablo 6'da verilmiştir. Tabloda görüldüğü gibi, faktör 1 , faktör 2 ve toplam puanların anlamlı derecede farklılaşmadığı görülmüş ve değerlendirmeciler arasında tutarlılık olduğu kabul edilmiştir.

Tablo 6. OGBDÖ Ile Dört Değerlendirmeci Tarafindan Yapılan Değerlendirmelere İliş̧kin İlişkili Ölçümler İçin Friedman'ın İki Yönlü Varyans Analizi Sonuçları

\begin{tabular}{|c|c|c|c|c|c|c|c|c|c|c|c|c|}
\hline \multirow{2}{*}{ Değerlendirmeciler } & \multicolumn{4}{|c|}{ Faktör 1} & \multicolumn{4}{|c|}{ Faktör 2} & \multicolumn{4}{|c|}{ Toplam Puan } \\
\hline & $\begin{array}{l}\text { Sira } \\
\text { Ort. }\end{array}$ & $\mathrm{sd}$ & $\chi^{2}$ & $\mathrm{p}$ & $\begin{array}{l}\text { Sira } \\
\text { Ort. }\end{array}$ & $\mathrm{sd}$ & $\chi^{2}$ & $\mathrm{p}$ & $\begin{array}{l}\text { Sira } \\
\text { Ort. }\end{array}$ & sd & $\chi^{2}$ & $\mathrm{p}$ \\
\hline 1 & 2.44 & & & & 2.89 & & & & 2.67 & & & \\
\hline 2 & 2.28 & 3 & 2.01 & .56 & 2.89 & 3 & 6.04 & .11 & 2.61 & 3 & 2.39 & .49 \\
\hline 3 & 2.33 & & & & 2.50 & & & & 2.00 & & & \\
\hline 4 & 2.94 & & & & 1.72 & & & & 2.72 & & & \\
\hline
\end{tabular}

\section{TARTIŞMA VE SONUÇ}

$\mathrm{Bu}$ araştırmada 3-6 yaş grubundaki gelişimsel geriliği olan ve olmayan çocukların geçiş becerilerini değerlendirmek amacıyla bir ölçme aracı geliştirilmiş; aracın psikometrik özellikleri incelenmiştir. OGBDÖ’nin, geçerliğini test etmek için faktör analizi, madde analizi ve ölçüt geçerliği; güvenirliğini test etmek için ise iç tutarlılık, test-tekrar test korelasyonu ve değerlendirmeciler arası tutarlık çalışmaları yapılmıştır. Analizler sonucunda ölçeğin okulöncesi çocukların geçiş becerilerini değerlendirmede geçerli ve güvenilir bir araç olduğu sonucuna ulaşılmıştır. EK 1'de geçerlik ve güvenirlik çalışmalarının sonucunda kullanıma hazır hale getirilen OGBDÖ, yönergesi ile birlikte verilmiştir.

OGBDÖ'nin faktör yapısını belirlemek için yapılan faktör analizi sonucunda elde edilen iki faktörün ve faktörlerde yer alan becerilerin alan yazında incelenen ölçme araçlarıyla (Rosenkoetter ve ark., 1994; Akt. Rous \& Hallam, 1998) benzerlikler gösterdiği bulunmuştur. Ancak OGBDÖ’ndeki özbakım becerilerinin alan yazındaki ölçme araçlarında yer almadığı görülmüştür. Ülkemizde okulöncesi yöneticiler ve öğretmenlerin büyük çoğunluğu özbakım becerilerin önemini vurgulamış ve bu beceriler OGBDÖ'nde ayrı bir faktör olarak yer almıştır. Bu sonucun kültürel bir özellik olduğu ve ülkemizde okulöncesi dönemde en az sosyal-iletişimsel 
beceriler kadar özbakım becerilerine de önem verildiği ve bu becerilerin geçişte önemli olduğunun düşünüldüğü kabul edilebilir.

OGBDÖ'ndeki maddelerin ait oldukları faktör yük değerlerinin yüksek olması, geçiş becerilerini ölçmek için oluşturulan kapsamın yeterli olduğunu göstermektedir. Varimaks dik döndürme öncesi maddelerin faktör yük değerlerinin de oldukça yüksek olması (.45-.82), ölçeğin tek faktörlülüğüne/boyutluluğuna işaret etmektedir. Bu nedenle ölçek hem tek faktörlü hem de iki faktörlü olarak kullanılabilecektir (Büyüköztürk, 2002). $\mathrm{Bu}$ durum, ölçme aracını kullanmak isteyen araştırmacılara tek bir toplam puan üzerinden çalışma seçeneği de sunmaktadır. Ayrıca ölçeğin ölçüt geçerliği çalışmasında, gelişimsel geriliği olan ve olmayan çocukların iki faktör ve toplam puan ortalamaları arasında anlamlı fark olduğu ve ölçeğin iki grubu ayırt ettiği bulunmuştur. Bu sonuçlar OGBDÖ'nin hem gelişimsel geriliği olan hem de olmayan çocukların geçiş becerilerini değerlendirmede geçerli bir araç olduğunu göstermektedir.

Alan yazında belirtildiği gibi (Brown, Odom, Li, \& Zercher, 1999; Carta ve ark., 1990; Fowler ve ark., 1991; Haney \& Cavallaro, 1996; Le Ager \& Shapiro, 1995; Rule ve ark., 1990) gelişimsel geriliği olan ve olmayan çocukların okulöncesi programlara geçiş yaparken sahip oldukları becerilerin ölçeklerle değerlendirilmesinin yanı sıra kontrol listeleri, yeni ve eski programda yapılan doğrudan gözlemler, öğretmen/anne-baba/bakıcıyla görüşmeler, vb. yöntemlerle de değerlendirilmesi, eğitimcilere çok yönlü değerlendirme olanaği sunmaktadır. Okulöncesi dönemde geçiş yapan çocukların becerilerinin değerlendirilmesinde ülkemizde de farklı yöntemlerin kullanılabilmesi için, OGBDÖ'nin anne-baba formunun, öğretmen/anne-baba görüssme formlarının ve gözlem formlarının hazırlanması gibi gerekli çalışmalar yürütülmelidir. OGBDÖ ve diğer yöntemlerle yapılan değerlendirmeler 1şığında çocukların sahip olmadığ 1 ama yeni programda ihtiyaç duyacakları geçiş becerilerinin belirlenerek öğretilmesine yönelik çalışmaların (Fowler ve ark., 1991; Kemp ve Carter, 2000; Rule ve ark., 1990) yürütülmesi ve bu amaca yönelik geçiş programlarının hazırlanması, hem gelişimsel geriliği olan hem de olmayan çocukların okulöncesi programlarda başarılı olmasını ve geçiş yaptıkları ortamlara daha kolay uyum sağlamalarını sağlayacaktır. Geliştirilen OGBDÖ'nin, bu programlar için hedef/amaç belirlemenin yanı sıra programın etkililiğini saptamada öntest-sontest ölçüm arac1 olarak kullanılabileceği düşünülmektedir.

Son olarak geçiş becerilerinin kazanım yaşları kesin değildir ve bütün okulöncesi kurumlara giriş için uygun olan özel bir beceri listesinin hazırlanması mümkün görünmemektedir. Bu nedenle herhangi bir programa 
yerleştirme için, bu ölçekte yer alan becerilerin kazanılıp kazanılmadığı önkoşul oluşturmamalıdır. Bununla birlikte özellikle kaynaştırma programlarına hazırlanan gelişimsel geriliği olan çocukların öğretim programları oluşturulurken OGBDÖ'nin amaçların saptanmasında kullanılabileceği, çocuğun yetersiz olduğu geçiş becerilerinin öğretim programına yerleştirilerek öğretilebileceği ve becerilerin öğretilmesiyle çocukların yeni programa uyumlarının kolaylaştırılabileceği ümit edilmektedir.

\section{KAYNAKÇA}

Brown, W.H., Odom, S.L., Li, S., \& Zercher, C. (1999). Ecobehavioral assessment in early childhood programs: A portrait of preschool inclusion. The Journal of Special Education, 33 (3), 138-153.

Bruder, M.B. \& Chandler, L.K. (1993). Transition. In S.L. Odom \& M.E. McLean (Eds.). DEC recommended practices: Indicators of quality in programs for infants and young children with special needs and their families (pp. 96-105). Denver: The Council for Exceptional Children.

Büyüköztürk, Ş. (2002). Sosyal bilimler için veri analizi elkitabl: İstatistik, araştırma deseni, SPSS uygulamalart ve yorum. Ankara: Pegem A Yayıncilik.

Carta, J.J., Atwater, J.B., Schwartz, I.S., \& Miller, P.A. (1990). Applications of ecobehavioral analysis to the study of transitions across early education setting. Education and Treatment of Children, 13 (4), 298-314.

Fowler, S.A., Schwartz, I., \& Atwater, J. (1991). Perspectives on the transition from preschool to kindergarten for children with disabilities and their families. Exceptional Children, 58 (2), 136-145.

Haney, M. \& Cavallaro, C.C. (1996). Using ecological assessment in daily program planning for children with disabilities in typical preschool setting. Topics in Early Childhood Special Education, 16 (1), 66-81.

Hanson, M.J. (1999). Early transitions for children and families: Transitions from infant/toddler services to preschool education. (Eric Document Reproduction Service No. ED 434436).

Hanson, M.J., Beckman, P.J., Horn, E., Marquart, J., Sandall, S.R., Greig, D., \& Brennan, E. (2000). Entering preschool: Family and professional experiences in this transition process. Journal of Early Intervention, 23 (4), 279-293.

Kargın, T., Akçamete, G., \& Baydık, B. (2001). Okulöncesi yaşta çocuğu bulunan ailelerin geçiş sürecindeki gereksinimlerinin belirlenmesi. Özel Ĕgitim Dergisi, 3 (1), 13-24. 
Katims, D.S. \& Pierce, P.L. (1995). Literary-rich environments and the transition of young children with special needs. Topics in Early Childhood Special Education, 15 (2), 219-226.

Katz, L.G. (1991). Readiness: Children and schools. (Eric Document Reproduction Service No. ED 330595).

Kemp, C. \& Carter, M. (2000). Demonstration of classroom survival skills in kinderegarten: A five-year transition study of children with intellectual disabilities. Educational Psychology, 29 (4), 393-411.

Le Ager, C. \& Shapiro, E. (1995). Template matching as a strategy for assessment of and intervention for preschool students with disabilities. Topics in Early Childhood Special Education, 15 (2), 187-219.

Lombardi, J. (1992). Beyond transition: Ensuring continuity in early childhood services. (Eric Document Reproduction Service No. ED345867).

Maxwell, K.L. \& Eller, S.K. (1994). Children's transition to kindergarten. Young Children, 49 (6), 56-63.

Özgüven, E. (1994). Psikolojik testler. Ankara: Yeni Doğuş Matbaası.

Pianta, R.C. \& Kraft-Sayre, M. (1999). Parents' observations about their children's transition to kindergarten. Young Children, 54 (3), 47-52.

Poyraz-Tüy, S. (1999). 3-6 yaş arasındaki işitme engelli ve işiten çocukların sosyal beceri ve problem davranışlar yönünden karşılaştırılmaları. Yayımlanmamış yüksek lisans tezi, Ankara Üniversitesi, Ankara.

Repetto, J.B. \& Correa, V.I. (1996). Expanding views on transition. Exceptional Children, 62 (6), 551-563.

Rosenkoetter, S.E., Hains, A.H., \& Fowler, S.A. (1994). Bridging early services for children with special needs and their families: A practical guide for transition planning. Baltimore: Paul H. Brookes Publishing Co

Rosenkoetter, S.E., Whaley, K.T., Hains, A.H., \& Pierce, L. (2001). The evolution of transition policy for young children with special needs and their families. Topics in Early Childhood Special Education, 21 (1), 3-16.

Rous, B. (1999). Project STEPS: Sequenced transition to education in the public schools. National Outreach Project. Final Evaluation Report, 1996-1999.

Rous, B., Hemmeter, M.L., \& Schuster, J. (1994). Sequenced transition to education in the public schools: A systems approach to transition planning. Topics in Early Childhood Special Education, 14 (3), 374-393.

Rous, B. \& Hallam, R.A. (1998). Easing the transition to kindergarten: Assessment of social, behavioral, and functional skills in young children with disabilities. Young Exceptional Children, 1 (4), 17-28.

Rule, S. Fiechtl, B.J., \& Innocenti, M.S. (1990). Preparation for transition to mainstreamed post-preschool environments: Development of a survival 
skills curriculum. Topics in Early Childhood Special Education, 9 (4), 78 90.

Tezbaşaran, A. (1997). Likert tipi ölçek geliştirme kılavuzu. Ankara: Türk Psikologlar Derneği Yayınlan.

Westling, D.L. \& Fox, L. (2000). Teaching students with severe disabilities. Prentice-Hall, Inc.

Wolery, M. (1989). Transitions in early childhood special education: Issues and procedures. Focus on Exceptional Children, 22 (2), 1-16.

Wolery, M. (1999). Children with disabilities in elementary school. In R.C. Pianta \& M.J. Cox (Eds.), The transition to kindergarten (pp. 253-280). Paul H. Brookes Publishing Co.

\section{EK 1: OKULÖNCESİ GEÇİŞ BECERILERINII DEĞERLENDİRME ÖLÇEĞI}

Sevgili öğretmenler, Okulöncesi Geçiş Becerilerini Değerlendirme Ölçeği, 3-6 yaş arasındaki çocukların okulöncesi programlara geçiş yaparken sahip oldukları geçiş becerilerini değerlendirmek amaciyla geliştirilmiştir. Lütfen ölçeği en az 6 ay süreyle tanıdığınız çocuklar için doldurunuz. Her beceri için değerlendirme yapmadan önce, çocuğa ait kimlik bilgilerini aşağyya kaydediniz. Ölçekte yer alan becerileri dikkatle okuyunuz, aşağıdaki anahtarı ve örneği göz önüne alarak çocuğun becerilerinin derecesini en iyi ifade ettiğini düşündüğünüz seçeneğin (sayının) altındaki sütuna " $X$ " işareti koyunuz.

Aşağıda 1, 3 ve 5 seçeneklerinin davranışsal olarak tanımları verilmiştir. Çocuğun ölçekte yer alan becerileri yerine getirme düzeyine göre çocuğu 1,3 ve 5 seçeneklerine göre değerlendiriniz. 1 ve 3 seçenekleri arasında kararsız kaldığınızda 2; 3 ve 5 seçenekleri arasında kararsız kaldığınızda ise 4 seçeneğini işaretleyiniz.

1 (Tamamen yardımla yapar.): Çocuk beceriyi yerine getirirken her seferinde yetişkinlerin/arkadaşlarının fiziksel ya da sözel yardımına gereksinim duyabilmektedir.

3 (Bazen yardımla yapar.): Çocuk beceriyi yerine getirirken bazen yetişkinlerin/arkadaşlarının fiziksel ya da sözel yardımına gereksinim duymakta, bazen de beceriyi yardımsız olarak yerine getirebilmektedir.

5 (Tamamen yardımsız yapar.): Çocuk beceriyi yerine getirirken hiç yardıma gereksinim duymaksızın, beceriyi bağımsız olarak yerine getirebilmektedir. 
Çocuğun Adı-Soyadı:

Çocuğun Yaşı:

Çocuğun Cinsiyeti:

Öğretmenin Adı-Soyadı:

Değerlendirme Tarihi:

Kurumun Adı:

Çocuğun Gelişimsel Geriliği/Problemi Var mı?

Varsa Tanısi:

\begin{tabular}{|c|c|c|c|c|c|}
\hline Beceriler & $\begin{array}{c}\mathbf{1} \\
\text { Tamamen } \\
\text { Yardımla } \\
\text { Yapar } \\
\end{array}$ & 2 & $\begin{array}{c}\mathbf{3} \\
\text { Bazen } \\
\text { Yardımla } \\
\text { Yapar } \\
\end{array}$ & 4 & $\begin{array}{c}\mathbf{5} \\
\text { Tamamen } \\
\text { Yardımsız } \\
\text { Yapar } \\
\end{array}$ \\
\hline \multicolumn{6}{|l|}{ 1. Tuvaletini yapar. } \\
\hline \multicolumn{6}{|l|}{ 2. Yemek yer. } \\
\hline \multicolumn{6}{|l|}{ 3. Giyinir ve soyunur. } \\
\hline \multicolumn{6}{|l|}{ 4. Ellerini yikar ve kurular. } \\
\hline \multicolumn{6}{|l|}{ 5. Dişlerini firçalar. } \\
\hline \multicolumn{6}{|l|}{$\begin{array}{l}\text { 6. Jestlerle, mimiklerle, seslerle, sözcüklerle yetişkinlerle ya da } \\
\text { arkadaşlarıyla iletişim kurar. }\end{array}$} \\
\hline \multicolumn{6}{|l|}{$\begin{array}{l}\text { 7. Okula ya da kendisine ait materyalleri ya da yiyecekleri diğerleriyle } \\
\text { paylaşr. }\end{array}$} \\
\hline \multicolumn{6}{|l|}{ 8. Yönergelere uyar. } \\
\hline \multicolumn{6}{|l|}{ 9. Sorulara yanit verir. } \\
\hline \multicolumn{6}{|l|}{ 10. Serbest zaman ya da yapilandirılmış grup etkinliklerine katilır. } \\
\hline \multicolumn{6}{|l|}{ 11. İsteklerini ya da ihtiyaçlarıı belirtir. } \\
\hline \multicolumn{6}{|l|}{ 12. İstenildiğinde yerinde oturur ve bekler. } \\
\hline \multicolumn{6}{|l|}{ 13. Sira olur ve sirada bekler. } \\
\hline \multicolumn{6}{|l|}{$\begin{array}{l}\text { 14. Başa çıkamadığı durumlarda yetişkinden ya da arkadaşından } \\
\text { yardım ister. }\end{array}$} \\
\hline \multicolumn{6}{|l|}{ 15. Bir etkinlik üzerinde 3-5 dakika süreyle çalş̧r. } \\
\hline \multicolumn{6}{|l|}{ 16. Verilen görevi istenilen zamanda ve uygun şekilde tamamlar. } \\
\hline \multicolumn{6}{|l|}{ 17. Yetişkinler ya da arkadaşları konuşurken onları dinler. } \\
\hline \multicolumn{6}{|l|}{ 18. Teşekkür eder. } \\
\hline \multicolumn{6}{|l|}{$\begin{array}{l}\text { 19. Oyuncaklarn ya da materyalleri yerinden alır, işi bitince toplar ve } \\
\text { yerine kaldırr. }\end{array}$} \\
\hline \multicolumn{6}{|l|}{$\begin{array}{l}\text { 20. Günaydın ya da merhaba gibi sözcükleri ya da jestleri kullanarak } \\
\text { diğerleriyle selamlaşrr. }\end{array}$} \\
\hline \multicolumn{6}{|l|}{ 21. İstendiğinde bir etkinlikten diğerine kolayca geçiş yapar. } \\
\hline \multicolumn{6}{|l|}{ 22. Arkadaşlarının etkinliklerini bozmaktan kaçıır. } \\
\hline \multicolumn{6}{|l|}{ 23. Yeni şeyler öğrenirken yetişkinleri ya da arkadaşlarını taklit eder. } \\
\hline $\begin{array}{l}\text { 24. Yetişkinlerin ya da arkadaşlarının dikkatini uygun şekilde (el } \\
\text { kaldırarak, seslenerek ya da dokunarak) çeker. }\end{array}$ & & & & & \\
\hline
\end{tabular}

